\title{
THE EFFECT OF OESTROGEN AND PROGESTERONE ON THE RELEASE OF PROSTAGLANDINS FROM THE UTERUS OF THE OVARIECTOMIZED GUINEA-PIG
}

\author{
F. R. BLATCHLEY* AND N. L. POYSER $\dagger$ \\ *Department of Physiology, Institute of Psychiatry, London SE5 $8 A F$ \\ and $\uparrow$ Department of Pharmacology, University of Edinburgh, \\ 1 George Square, Edinburgh EH8 $97 Z$
}

(Received 22nd March 1974)

Evidence is accumulating (Blatchley \& Donovan, 1973) that the uterine luteolytic hormone in mammals is prostaglandin $\mathrm{F}_{2 \alpha}\left(\mathrm{PGF}_{2 \alpha}\right)$. This prostaglandin is released from the guinea-pig uterus under conditions associated with premature luteolysis, such as bead insertion (Poyser, Horton, Thompson \& Los, 1971) and oestrogen treatment (Blatchley, Donovan, Poyser, Horton, Thompson \& Los, 1971), and both the synthesis and release of $P_{G F}$ increase toward the end of the oestrous cycle when natural luteal regression occurs (Poyser, 1972; Blatchley, Donovan, Horton \& Poyser, 1972). The factors involved in the regulation of the cyclic release of prostaglandin from the uterus have not been extensively studied, although Pickles (1967) suggested that progesterone may regulate the synthesis of prostaglandins in the human uterus as the concentration of $\mathrm{F}$ prostaglandin in menstrual fluid was higher during ovulatory menstrual cycles than in anovular cycles.

As part of a study on the regulation of prostaglandin release from the uterus, the effect of gonadal steroids on the concentration of prostaglandin in the uteroovarian vein of ovariectomized guinea-pigs has been examined.

Eighteen cyclic guinea-pigs were bilaterally ovariectomized during the luteal phase of the cycle (Days 5 to 11). Twelve were given a 10.0-mg implant of progesterone (Organon) subcutaneously at the time of surgery; seven of these received no further treatment while $10.0 \mu \mathrm{g}$ oestradiol benzoate ('Oestroform', $\mathrm{BDH}$ ) daily was injected subcutaneously for 3 days into five females before blood collection. The remaining six ovariectomized females were treated only with oestradiol benzoate for 3 days.

Nine to 11 days after surgery, blood was collected from one utero-ovarian vein for a period of $1 \mathrm{hr}$ as previously described (Blatchley et al., 1972). After draining the blood into tubes surrounded by ice, it was centrifuged as soon as possible and the plasma was stored at $-20^{\circ} \mathrm{C}$ until assay.

A 1-ml aliquot of plasma from each sample was saved, and the remainder of the plasma from animals in any one group was amalgamated. The prostaglandin content of the pooled plasma samples was measured by bioassay, using the rat fundal strip, following purification by organic solvent partition and column chromatography. Identification of $\mathrm{PGF}_{2 \alpha}$ was confirmed by combined 
gas chromatography and mass spectrometry (GC-MS). These methods have been described previously (Blatchley et al., 1972).

The 1-ml plasma samples were used for measuring PGF levels by radioimmunoassay (RIA). The antibody to $\mathrm{PGF}_{2 \alpha}$ was raised in rabbits and tested in one of our laboratories (Edinburgh) by methods to be described (H. A. Emslie, L. K. Henderson and F. Rutherford, in preparation). Only cross-reactivity with prostaglandin $\mathrm{F}_{1 \alpha}(73 \%)$ was significant (cross-reactivity with $\mathrm{PGF}_{2 \alpha}$ was $100 \%$ ) whilst prostaglandin $\mathrm{E}_{2}$ and other prostaglandins and metabolites cross-reacted by less than $0.7 \%$. Accuracy was assessed by assaying the prostaglandin content of female guinea-pig peripheral plasma to which $6 \mathrm{ng} / \mathrm{ml} \mathrm{PGF}_{2 \alpha}$ had been added. The mean value obtained in seventeen assays was $6.27 \pm 0.21 \mathrm{ng} / \mathrm{ml}$.

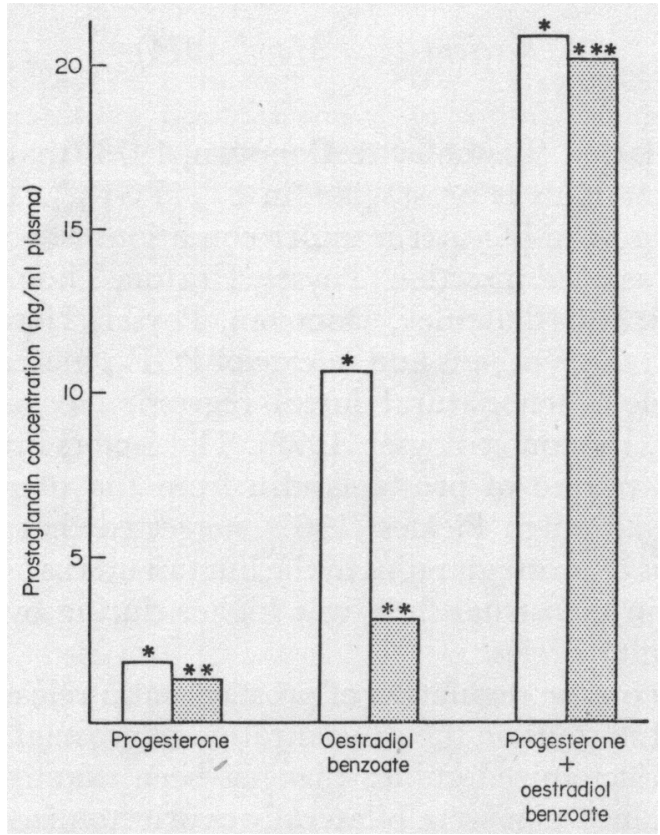

\begin{abstract}
TEXT-FIG. 1. Prostaglandin concentrations, measured by bioassay, in the utero-ovarian vein plasma of ovariectomized guinea-pigs treated with (i) a $10.0 \mathrm{mg}$ implant of progesterone from the time of surgery, (ii) $10 \cdot 0 \mu \mathrm{g}$ oestradiol benzoate injected daily for 3 days before blood collection, or (iii) with a combination of these treatments. Open columns represent prostaglandin $\mathrm{F}_{2 \alpha}$; hatched columns represent a prostaglandin E-like material, probably $\mathrm{PGE}_{2}$.

* Result confirmed by GC-MS; ** not subjected to GG-MS; *** sample subjected to GC-MS, but interfering factors made positive identification impossible.
\end{abstract}

Two aliquots (of between 0.01 and $0.4 \mathrm{ml}$ ) were taken for analysis from each $1 \mathrm{ml}$ plasma. The volume was made up to $0.2 \mathrm{ml}$, if required, and the $\mathrm{pH}$ was lowered by adding 0.5 vols $0.1 \mathrm{M}$-citrate buffer at $\mathrm{pH} 4$. Each aliquot was extracted with $2 \mathrm{ml}$ redistilled ethyl acetate which was decanted after freezing the plasma. This was repeated, the two ethyl acetate fractions were combined, and the ethyl acetate was blown off with air at $45^{\circ} \mathrm{G}$. (The recovery of tritiated $\mathrm{PGF}_{2 \alpha}$ from guinea-pig plasma by this method was found to exceed $91 \%$.) The PGF content of the dried extracts was then measured by RIA (using a double anti- 
body technique), and the level of PGF in the original plasma sample was taken as the mean of the two values obtained.

The concentrations of prostaglandins found in the utero-ovarian vein plasma of guinea-pigs under the various hormonal treatments (as measured by bioassay) are illustrated in Text-fig. 1. Under the influence of progesterone alone, the release of $\mathrm{PGF}_{2 \alpha}$ into the utero-ovarian venous plasma was minimal $(<1.8$ $\mathrm{ng} / \mathrm{ml}$ ), whilst oestrogen alone markedly increased the amount of $\mathrm{PGF}_{2 \alpha}$ released $(10.7 \mathrm{ng} / \mathrm{ml})$. Neither hormone by itself, however, was as effective as the combined treatment which greatly increased the level of $\mathrm{PGF}_{2 \alpha}$ in the utero-ovarian venous plasma $(20.9 \mathrm{ng} / \mathrm{ml})$. This value was similar to that of oestrogen-treated guinea-pigs on Day 7 of the oestrous cycle which was $21 \cdot 1 \pm 5 \cdot 3 \mathrm{ng} / \mathrm{ml}$ plasma (Blatchley et al., 1971).

Table 1. The concentration of $\mathrm{PGF}_{2 \alpha}$, measured by radioimmunoassay, in utero-ovarian venous plasma of ovariectomized guinea-pigs subjected to various hormonal treatments

\begin{tabular}{c|c|c|c}
\hline & Treatment & $\begin{array}{c}P G F_{2 \alpha} \text { concentration } \\
(\mathrm{ng} / \mathrm{ml} \text { plasma })\end{array}$ & $\begin{array}{c}\text { Group mean } \\
\text { (ng/ml plasma })\end{array}$ \\
\hline 5668 & Progesterone implant $(10 \mathrm{mg})$ & $3 \cdot 2$ & $3 \cdot 7$ \\
5726 & & $3 \cdot 8$ & \\
5752 & & $5 \cdot 7$ & \\
5785 & & $3 \cdot 0$ & \\
5794 & & $2 \cdot 0$ & \\
5823 & & $2 \cdot 5$ & $12 \cdot 0$ \\
3737 & Oestradiol benzoate $(10 \mu \mathrm{g})$ & $36 \cdot 5$ & \\
3768 & for 3 days & $5 \cdot 8$ & \\
3839 & & $4 \cdot 8$ & \\
3856 & & $2 \cdot 8$ & \\
3895 & & $5 \cdot 6$ & \\
3898 & & $16 \cdot 5$ & \\
4312 & Progesterone implant $(10 \mathrm{mg})$ & $15 \cdot 8$ & \\
4315 & toestradiol benzoate $(10 \mu \mathrm{g})$ & $100 \cdot 0$ & \\
5319 & for 3 days & $14 \cdot 3$ & \\
5572 & & $11 \cdot 2$ & \\
5614 & & $31 \cdot 0$ & \\
& & & \\
\hline
\end{tabular}

When the $\mathrm{PGF}_{2 \alpha}$ content of the utero-ovarian venous plasma of individual guinea-pigs was measured by RIA, the mean results obtained for each treatment group were essentially similar to those obtained by bioassay (see Table 1), but the variation between animals in two of the groups was considerable. Only two of the six animals treated with oestrogen alone showed an increase in PGF $_{2 \alpha}$ concentration in the utero-ovarian venous plasma compared with those treated with progesterone alone; after combined hormone treatment, however, increased amounts of $\mathrm{PGF}_{2 \alpha}$ were released in all five animals, although the variation in this group was very large.

Although prostaglandins of the $\mathrm{E}$ series (PGE) were sought in the blood collected from all three groups, neither hormone treatment alone resulted in any measurable PGE release, the value for the progesterone-treated animals being $<1.3 \mathrm{ng} / \mathrm{ml}$ plasma and for oestrogen-treated animals $<3.2 \mathrm{ng} / \mathrm{ml}$ plasma (see 
Text-fig. 1). After combined treatment, however, $20 \cdot 2 \mathrm{ng} / \mathrm{ml}$ PGE-like (assayed as $\mathrm{PGE}_{2}$ ) material was measured by bioassay in the plasma draining the uterus, but unfortunately, when subjected to GC-MS, the presence of interfering factors prevented positive identification of PGE.

The results reported here are in broad agreement with those obtained in other species. Saksena \& Lau (1973) found that the highest levels of PGF $2 \alpha$ occurred in uterine tissue homogenates from ovariectomized mice treated with oestrogen and progesterone, although either hormone alone caused a significant increase over the production found in oil-injected controls. Pretreatment with progesterone and an injection of oestrogen are necessary to produce a rise in the peripheral plasma concentration of prostaglandin $F$ in the ovariectomized ewe similar to that seen at the end of the normal oestrous cycle (Caldwell, Tillson, Brock \& Speroff, 1972). The fluid which collects in the uterine lumen of sheep bearing ovaries autotransplanted to a neck skin loop is rich in $\mathrm{PGF}_{2 \alpha}$ (Harrison, Heap, Horton \& Poyser, 1972). This experimental situation results in high and persistent progesterone levels but oestrogen production from the ovaries and/or adrenals may have contributed to the effect produced.

Since prostaglandins are not stored in the tissues producing them (see Poyser, 1973), our results in the guinea-pig show that oestrogen alone can stimulate the synthesis by, and release from, the uterus of $\mathrm{PGF}_{2 \alpha}$. This effect is potentiated in the presence of progesterone. Joshi, Watson \& Labhsetwar (1973) have shown ovarian venous plasma levels of oestradiol to increase between Days 9 to 11 and Days 13 to 15 . These increases in oestradiol levels coincide exactly with increases in the level of $\mathrm{PGF}_{2 \alpha}$ in the utero-ovarian venous blood (Blatchley et al., 1972). It is reasonable to suggest that oestrogen and progesterone together form the physiological stimulus for the output of $\mathrm{PGF}_{2 \alpha}$ from the uterus in the guineapig.

We wish to thank Professor B. T. Donovan and Professor E. W. Horton for their valuable advice during these experiments and the writing of this manuscript. We are most grateful to Mrs Maureen Harrison for technical assistance and to the Population Council and the Medical Research Council for financial support. One of us (N.L.P.) is an M.R.G. Research Fellow.

\section{REFERENCES}

Blatchley, F. R. \& Donovan, B. T. (1973) Comparative aspects of luteolytic mechanisms. In Le Corps Jaune, p. 325. Eds. R. Denamur and A. Netter. Colloque de la Société Nationale pour l'Étude de la Stérilité et de la Fécondité, July 1973. Masson et Cie, Paris.

Blatchley, F. R., Donovan, B. T., Horton, E. W. \& Poyser, N. L. (1972) The release of prostaglandins and progestin into the utero-ovarian venous blood of guinea-pigs during the oestrous cycle and following oestrogen treatment. 7. Physiol., Lond. 223, 69.

Blatchley, F. R., Donovan, B. T., Poyser, N. L., Horton, E. W., Thompson, C. J. \& Los, M. (1971) Identification of prostaglandin $\mathrm{F}_{2 \alpha}$ in the utero-ovarian blood of guinea-pig after treatment with oestrogen. Nature, Lond. 230, 243.

Galdwell, B. V., Tillson, S. A., Brock, W. A. \& Speroff, L. (1972) The effects of exogenous progesterone and estradiol on prostaglandin F levels in ovariectomized ewes. Prostaglandins, 1, 217.

Harrison, R. A., Heap, R. B., Horton, E. W. \& Poyser, N. L. (1972) Identification of prostaglandin $\mathrm{F}_{2 \alpha}$ in uterine fluid from the non-pregnant sheep with an autotransplanted ovary. F. Endocr. 53, 215. 
Joshr, H. S., Watson, D. J. \& LABhSETwar, A. P. (1973) Ovarian secretion of oestradiol, oestrone, 20dihydroprogesterone and progesterone during the oestrous cycle of the guinea-pig. 7. Reprod. Fert. 35, 177.

Pickles, V. R. (1967) Prostaglandins in the human endometrium. Int. F. Fert. 12, 335.

Poyser, N. L. (1972) Production of prostaglandins by the guinea-pig uterus. F. Endocr. 54, 147.

Poyser, N. L. (1973) The physiology of prostaglandins. In Reproductive Endocrinology and World Population, p. 393. Ed. J. A. Loraine. Glinics in Endocrinology and Metabolism, 2. Saunders, London.

Poyser, N. L, Horton, E. W, Thompson, G. J. \& Los, M. (1971) Identification of prostaglandin F $_{2 \alpha}$ released by distension of guinea-pig uterus in vitro. Nature, Lond. 230, 526.

Saksena, S. K. \& LAU, I. F. (1973) Effect of exogenous estradiol and progesterone on the uterine tissue levels of prostaglandin $\mathrm{F}_{2 \alpha}\left(\mathrm{PGF}_{2 \alpha}\right)$ in ovariectomized mice. Prostaglandins, 3, 317. 